\title{
The Socio-Spatial Structure of a City: the Example of Zagreb
}

\author{
Vedran Prelogović
}

\begin{abstract}
This work provides a summarized overview of select aspects, concepts and results of foreign and Croatian research into the socio-spatial structure of a city. The status of the sociospatial structure of Zagreb has been determined through an analysis of statistical indicators of the socio-economic status of its population. The results show similarities between the socio-spatial structure of Zagreb and other postsocialist cities. The spatial pattern from the pre-transition period has been retained, and it is reflected in the declining socio-economic status of the population from the center to the peripheral sections of the city.
\end{abstract}

Key words: Zagreb, socio-spatial structure, postsocialist city, transition, educational structure, salaries, unemployment

\section{Socijalno-prostorna struktura grada: primjer Zagreba}

U radu su sažeto prikazani izabrani aspekti, koncepti i rezultati stranih i domaćih istraživanja socijalno-prostorne strukture grada. Analizom odabranih statističkih pokazatelja socijalno-ekonomskog statusa stanovništva utvrđeno je stanje socijalno-prostorne strukture Zagreba. Rezultati pokazuju sličnosti u socijalno-prostornoj strukturi Zagreba i drugih postsocijalističkih gradova. Prostorni obrazac iz predtranzicijskog razdoblja je zadržan, a očituje se u smanjuje socijalno-ekonomskog statusa stanovništva od središnjih prema rubnim dijelovima grada.

Ključne riječi: Zagreb, socijalno-prostorna struktura, postsocijalistički grad, tranzicija, obrazovna struktura, plaće, nezaposlenost

\section{INTRODUCTION}

The objective of this work is to provide a summarized overview of select aspects, concepts and results of foreign and Croatian research into the socio-spatial structure of a city, with particular emphasis on the last twenty years. The socio-spatial structure is considered separately, in the broader socio-economic context in which it emerged. This work has been prompted by the exceptionally dynamic socio-economic changes that have left their mark on the spatial structures of cities throughout the world. The purpose of this work is to portray the socio-spatial structure in Zagreb by using available statistical indicators, and to highlight the possibilities and importance of research into the spatial structure of cities. 
Social differentiation between cities, particularly over the last twenty years, are the topic of much geographic research. This interest has largely come to the fore in works by American and West European researchers, while the collapse of the socialist regimes and the great resulting changes have led scholars from Central and Eastern Europe to dedicate considerable attention to this problem. Research has shown that the socio-spatial structure of a city is closely tied to socio-economic development and urbanization, so that differences between developed and less developed countries become apparent as a result (Vresk 1986).

\section{RESEARCH INTO THE SOCIO-SPATIAL STRUCTURE OF CITIES}

\section{Countries with Developed Market Economies - Social Polarization in Cities}

Socio-spatial structure as a research topic appeared in geography and related disciplines in the first decades of the twentieth century. Geographic interest in analyzing socio-spatial structures intensified during the 1950s in a period marked by a positivist approach to science (Pacione 2001). Contemporary research has been prompted by changes in the global economy, which was reflected in the labor market-and this in turn influenced changes in the socio-spatial structures of cities. Changes in cities should be linked to the process of globalization and computerization, i.e. the appearance of the information society (Castells 1989, 1996). The application of new technologies in production and service activities, and the restructuring of capitalism, are visible in the economic, political, social and culture spheres (Vresk 2002). Changes at the global level are also reflected at the local level, particularly in the socio-economic structure of populations, and more and more research (Castells 1989; Burgers 1996; Sassen 2001; Stouten 2002) is confirming that social polarization is occurring in the cities of developed market economies.

The assertion of social polarization in cities was first made by Saskia Sassen ${ }^{1}$. Her assumption was that social polarization, expressed in income and occupations, is the result of a restructuring of production into service activities. Social polarization was first observed in highly-developed countries, in global cities above all. The principal spatial manifestation is the growth of upper and lower classes, to the detriment of the middle class. Sassen emphasizes three essential elements which contribute to polarization: growth of service activities and declining production activities (tertiarization), growth of highsalary jobs which increase demand for lower-paid jobs, and computerization of production activities (Sassen 2001). Numerous research worldwide has both confirmed and accented the complexity of this phenomenon (van Kempen 1994; Woodward 1995; Bruegel 1996; Burgers 1996; Clark \& McNicholas 1996).

Due to the different political, economic and social contexts in which socio-spatial structures change in American and West European cities, individual postulates of social polarization theory have been contested or even disproved (Woodward 1995; Badcock 1997; Hamnett 1994, 1996a, 1996b, 1998, 2001; Hamnet \& Cross 1998). This particularly pertains to the increasing growth of the lower classes, i.e. the appearance of poverty in cities, which has been proven only in certain global cities. Hamnett, using the example of London and Randstad Holland, showed that over the last twenty years the social structure of the employed population and the distribution of income do not indicate the presence of 
polarization processes, rather a process of professionalization. In other words, the number of well-paid professionals and middle-class jobs grew in absolute and relative terms, while the share of low-paying jobs remained at more or less the same level (Hamnett 1994, 1996a; Hamnett \& Cross, 1998). Research has shown that in countries with progressive welfare policies, such as the Scandinavian countries, social polarization is the least apparent (Wessel 2000, 2001; Andersen et al 2000; Andersen 2002).

\section{Cities in the Postsocialist Countries of Central and Eastern Europe - Changes in Socio-spatial Structure during Transition}

There were no notable differences in the socio-spatial structure of cities in the former socialist countries of Central and Eastern Europe; it was relatively homogenous (Häußermann 1997; Sykora 1999a, 1999b; Rebernik 2002; Vresk 2002). After the collapse of the socialist order, cities in this region underwent a transition from socialist to capitalist urban form (Sykora 1999a, 1999b). The process of transition from a planned to a market economy had considerable consequences for economic, political and social structures. A visible and explicit aspect of these changes is reflected in the socio-spatial structure of cities. After 1990, the following phenomena came to the fore: growth in unemployment, marked social segregation, increase in the share of upper and lower social classes, and broader zones of social exclusion (Węcławowicz 1997). Political changes and the introduction of a market economy led to increased social differentiation (Sykora 1999a; Kostynskiy 2001). Unemployment, poverty and growing social polarization are the most prominent contemporary features of the socio-spatial structure of cities in postsocialist countries (Węcławowicz 1997; Wießner 1997; Sykora 1999a; Kostynskiy 2001).

\section{Previous Research into Zagreb's Socio-spatial Structure}

All previous knowledge of the socio-spatial structure of Zagreb is tied to the period prior to the 1990s. The research results show a status similar to that in other socialist cities prior to transition. Marinović-Uzelac (1978) stressed that the socio-spatial structure of the city during the 1970s is a reflection of the status inherited from the prewar period (prior to 1945), which is characterized by more marked differentiation between social classes and the attempts of the socialist authorities to reduce such differences as much as possible. Bašić (1994a, 1994b) showed that in the period before the 1980s, differentiation was increasingly apparent in Zagreb with regard to the socio-economic and family status of the population, but that the socio-spatial structure was still relatively homogenous in comparison to cities in Western Europe.

\section{METHODOLOGICAL REMARKS}

This work presents the preliminary results of research into the socio-spatial structure of Zagreb, which was conducted within the framework of the project "Croatia's Urban System and Spatial Organization." The basic thesis of this work is that the socio-spatial structure changed even in Zagreb over the last twenty years. The changes were caused by the transition from a planned to a market economy. An attempt will be made to answer the following key questions: 
- what is the status of the socio-spatial structure today (i.e. in the transition period)?

- what is the role of transition processes in the creation of the city's socio-spatial structure?

- are there similarities (links) with cities in Western Europe and postsocialist Europe, i.e. in the theoretical and methodological points of departure?

The analysis of the socio-spatial structure is based on statistical data from the census of the population, households and domiciles in 2001. The problems encountered in the analysis were: differing census methods, changes in the administrative and territorial organization of the city and the spatial level of the data released. All postwar population censuses up to and including 1991 were conducted based on the concept of a permanent population (de iure), while the last census in 2001 was conducted based on the principle of a modified present population, so problems of comparability between the last census with all other postwar censuses emerged. Up to 1990, the territory of the current City was divided into 11 urban districts, while since 1997 the City of Zagreb has had a new administrative/territorial organization under which it is divided into 17 urban districts. Therefore, any comparisons or observations of intercensus changes have been rendered difficult, if not impossible. It is for this reason, and to secure the widest possible representation, that data from the 2001 census are used, and where any manner of comparison was possible, data from the 1981 and 1991 censuses, and the results of earlier research, are used (Vresk 1986; Bašić 1994a, 1994b, 1994c).

The spatial analysis pertains to the administrative and territorial unit of the City of Zagreb. ${ }^{2}$ The analysis was conducted at the level of the 17 urban districts, given that these are the smallest spatial units for which there is orderly and published statistical documentation. It is precisely the lack of published data at lower levels that prevents the creation of a more realistic picture of the status of the socio-spatial structure. The following socioeconomic indicators were considered: educational structure, salaries, and unemployment. The assumption is that these indicators best reflect changes in the transitional phase of development and that the greatest deviations between individual population categories (as in other postsocialist cities) would be reflected in precisely these indicators. The 17 urban districts encompass two urban settlements, Zagreb and Sesvete, and the urbanized and rural sections of the peri-urban zone. According to the last census, the City of Zagreb has a population of 779,145 . In numerical terms, Zagreb with a population of 691,724 , or $88.6 \%$ of the total population, and Sesvete, with a population of 44,914 or $5.6 \%$ of the total, stand out. The remaining 68 settlements have a population of 42,507 or $5.8 \%$ of the total population. Therefore, almost $95 \%$ of the population lives in a more or less compact and developed urban region. The remaining 5-6\%, which encompasses the population in smaller settlements of the peri-urban zone, do not greatly influence the end results of the research.

\section{RESEARCH RESULTS}

Research up to this point has indicated three aspects that are reflected in the sociospatial structure of the city. These are the socio-economic, family and ethnic status of the 
population. The most significant among them is the socio-economic status, determined by occupation, education (qualifications) and income. Family status is defined by bio-dynamic and structural features of the population such as: fertility, age structure, and family size. Socio-economic and family status can be deemed universal indicators of socio-spatial structure, while ethnic status is specific to cities marked by intense international immigration (this is particularly true of Anglo-American cities and those in certain West European countries) (Bašić 1994a). Each of these aspects shows a different spatial pattern. Thus, for example, socio-economic status indicates a tendency of concentration by sectors, family status most frequently appears in radial zones, while ethnic groups concentrate and segregate by cores (Pacione 2001).

The analysis of the socio-spatial structure is based — as noted previously —on the socio-economic indicators derived from the 2001 census, and on a comparison with prior censuses and research.

\section{Educational Structure.}

Previous research into socio-spatial structures in the world has established that occupations, education and income are the best indicators of a population's socio-economic status, with a high degree of mutual correlation. Out of these indicators, data on educational structure are the only data for which there are organized and published statistics at the level of city districts, so they shall be considered in more detail.

Tab. 1 Educational structure of the population of the City of Zagreb, 1981-2001

Tab. 1. Obrazovna struktura stanovništva Grada Zagreba 1981.-2001. godine

\begin{tabular}{|l|r|r|r|r|r|r|}
\hline Educational structure & $\mathbf{1 9 8 1}$ & $\mathbf{\%}$ & $\mathbf{1 9 9 1}$ & $\mathbf{\%}$ & $\mathbf{2 0 0 1}$ & $\mathbf{\%}$ \\
\hline $\begin{array}{l}\text { No schooling or incomplete } \\
\text { elementary schooling }\end{array}$ & 190528 & 27,9 & 91731 & 14,5 & 56969 & 8,6 \\
\hline Elementary school & 123253 & 18,0 & 131686 & 20,7 & 106829 & 16,3 \\
\hline Secondary school & 275444 & 40,3 & 285891 & 45,0 & 341344 & 52,0 \\
\hline College education & 25313 & 3,7 & 35861 & 5,6 & 38157 & 5,8 \\
\hline University education & 60949 & 8,9 & 81847 & 12,9 & 109323 & 16,7 \\
\hline Unknown & 8198 & 1,2 & 8413 & 1,3 & 3560 & 0,6 \\
\hline Total & $\mathbf{6 8 3 5 8 5}$ & $\mathbf{1 0 0 , 0}$ & $\mathbf{6 3 5} \mathbf{4 2 9}$ & $\mathbf{1 0 0 , 0}$ & $\mathbf{6 5 6} \mathbf{1 8 2}$ & $\mathbf{1 0 0 , 0}$ \\
\hline
\end{tabular}

Source: Statistički godišnjak Zagreba, Gradski zavod za planiranje razvoja i zaštitu čovjekova okoliša, Zagreb, 1991., Statistički ljetopis Zagreba 2002., Gradski zavod za planiranje razvoja grada i zaštitu okoliša, Zagreb, 2002.Protection Office, Zagreb, 2002.

Izvor: Statistički godišnjak Zagreba, Gradski zavod za planiranje razvoja i zaštitu čovjekova okoliša, Zagreb, 1991., Statistički ljetopis Zagreba 2002., Gradski zavod za planiranje razvoja grada i zaštitu okoliša, Zagreb, 2002. 
Data on educational structure encompass the population which was aged 15 years and over at the time of the census. According to the results of the last, 2001 census, $8.6 \%$ of the contingent encompassed in the City of Zagreb had no educational qualifications nor completed elementary school. If the $16.3 \%$ with only elementary school completed are added to this, one can see that in 2001 one fourth of the population of the City of Zagreb had an insufficient educational level. Regardless of this negative data, such a structure represents considerable progress in comparison to the situation ten or twenty years ago,

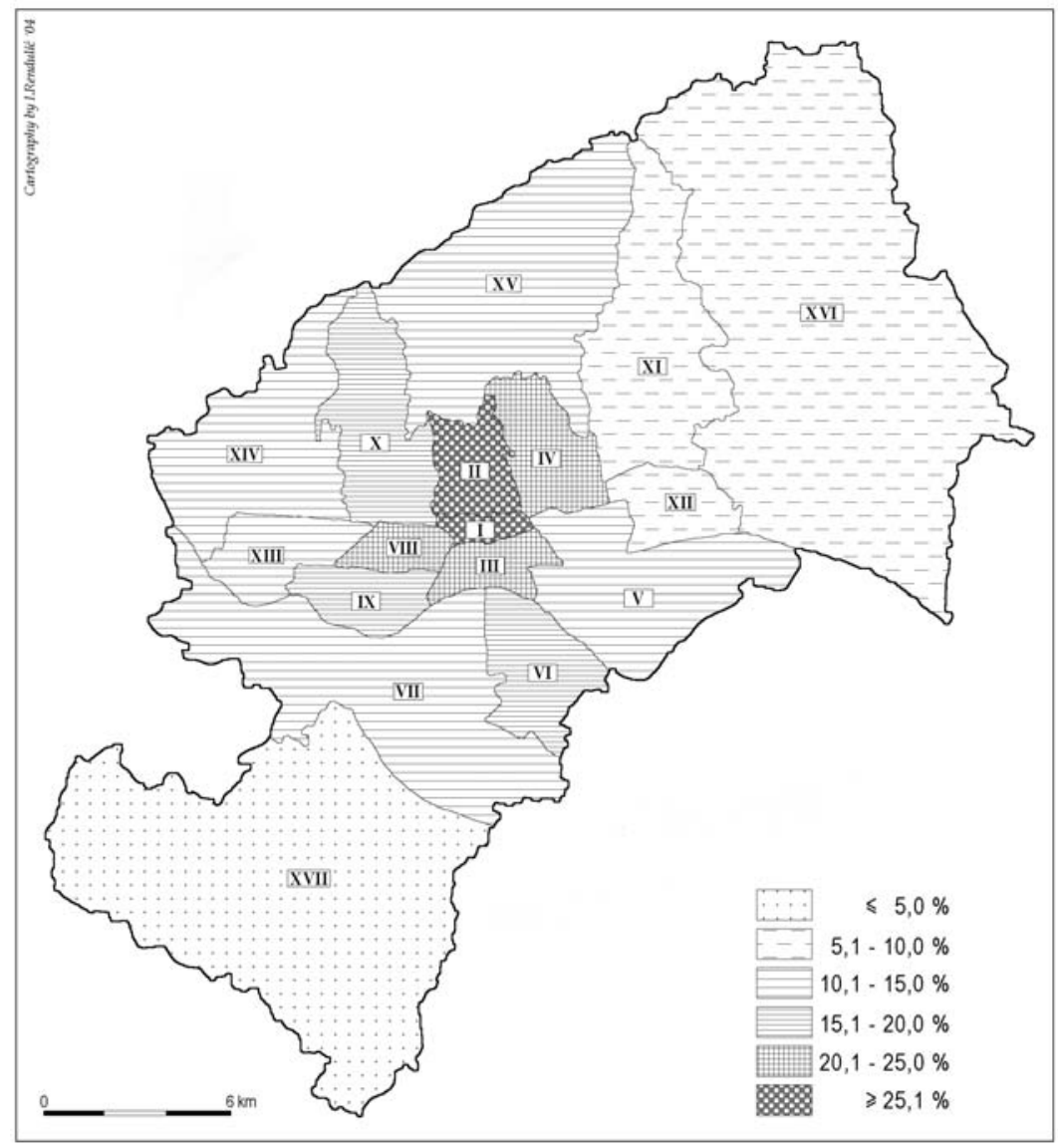

Fig. 1 Population aged 15 and over based on education - with completed higher or university education, by city districts in the City of Zagreb, 2001

(I Donji grad, II Gornji grad-Medveščak, III Trnje, IV Maksimir, V Pečćenica-Žitnjak, VI Novi Zagreb-istok, VII Novi Zagreb-zapad, VIII Trešnjevka-sjever, IX Trešnjevka-jug, X Črnomerc, XI Gornja Dubrava, XII Donja Dubrava, XIII Stenjevec, XIV Podused-Vrapče, XV Podsljeme, XVI Sesvete, XVII Brezovica)

Sl. 1. Stanovništvo staro 15 i više godina prema školskoj spremi-sa završenom višom ili visokom školom, po gradskim četvrtima Grada Zagreba 2001. godine

(IDonjigrad, II Gornji grad-Medveščak, III Trnje, IV Maksimir, VPešćenica-Žitnjak, VINovi Zagreb-istok, VII Novi Zagreb-zapad, VIII Trešnjevka-sjever, IX Trešnjevka-jug, X Črnomerc, XI Gornja Dubrava, XII Donja Dubrava, XIII Stenjevec, XIV Podused-Vrapče, XV Podsljeme, XVI Sesvete, XVII Brezovica) 
as there was an increase in the share of persons with completed secondary and higher education and a decline in the share of less educated persons (Tab. 1). Improvements in the educational structure are a result of the general tendency of the growing quality of life, lower immigration of less educated persons from rural regions in Croatia and the republics of the former common state (particularly Bosnia-Herzegovina)—which "lowered" the average - and intra-city migration of a part of the population (younger and better educated) from central to peripheral city sections.

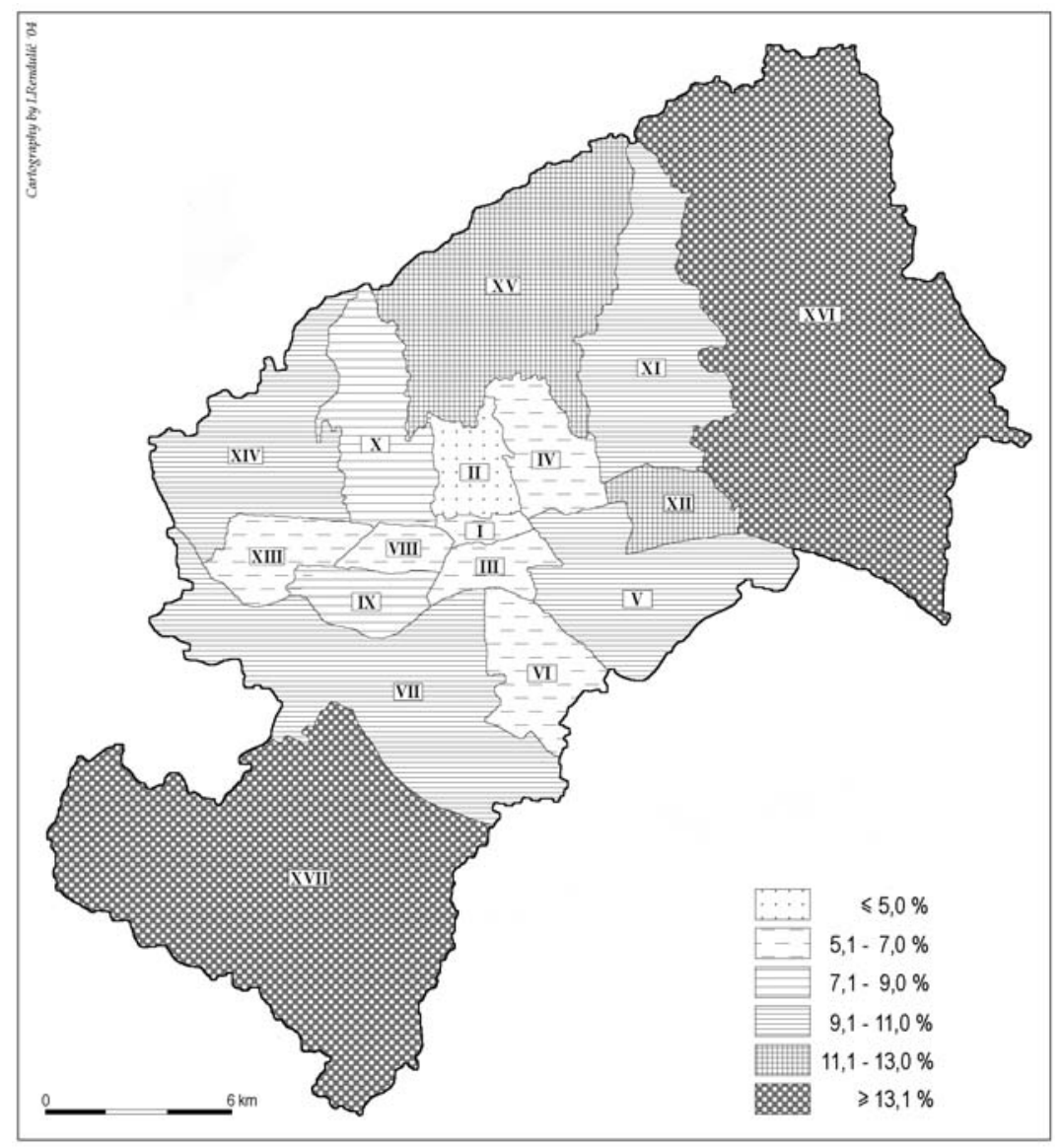

Fig. 2 Population aged 15 and over based on education - no or incomplete elementary education, by city districts in the City of Zagreb, 2001

(I Donji grad, II Gornji grad-Medveščak, III Trnje, IV Maksimir, V Pečćenica-Žitnjak, VI Novi Zagreb-istok, VII Novi Zagreb-zapad, VIII Trešnjevka-sjever, IX Trešnjevka-jug, X Črnomerc, XI Gornja Dubrava, XII Donja Dubrava, XIII Stenjevec, XIV Podused-Vrapče, XV Podsljeme, XVI Sesvete, XVII Brezovica)

Sl. 2. Stanovništvo staro 15 i višs godina prema školskoj spremi-bez osnovne škole i s nedovršenom osnovnom školom, po gradskim četvrtima Grada Zagreba 2001. godine

(I Donji grad, II Gornji grad-Medveščak, III Trnje, IV Maksimir, V Pečćenica-Žitnjak, VI Novi Zagreb-istok, VII Novi Zagreb-zapad, VIII Trešnjevka-sjever, IX Trešnjevka-jug, X Črnomerc, XI Gornja Dubrava, XII Donja Dubrava, XIII Stenjevec, XIV Podused-Vrapče, XV Podsljeme, XVI Sesvete, XVII Brezovica) 
"Going down" to the level of city districts provides a heterogeneous picture of the populations educational structure (Fig. 1 and 2). Differences in the extreme categories of the educated groups stand out. The share of the population without schooling or with incomplete schooling ranges from $3.8 \%$ in the Gornji grad-Medveščak to $13 \%$ in Donja Dubrava, or $15 \%$ to $22.4 \%$ in Sesvete and Brezovica. ${ }^{3}$ The educational level declines as one moves away from the city center, while zones with a large share of highly-educated persons have the least poorly-educated persons and the reverse, which also proves their internal homogeneity (Fig. 1 and 2).

The city districts in Zagreb's central zone, i.e. the Donji and Gornji grad-Medveščak, have the best educational structure. These are traditionally areas with a higher class of residents, which correspond to the neighborhoods with villas in the northern part of town and the residential neighborhoods constructed in the first half of the twentieth century ${ }^{4}$. The areas with heterogeneous educational structures correspond to the zones of postwar reconstruction and residential settlements constructed during the 1980s and 1990s. The lowest educational structure can be found in the peripheral city districts which largely correspond to zones with poorer residential structures, in the less urbanized and more rural parts of the peri-urban zone of the City of Zagreb.

In a word, the educational structure of the population in the City of Zagreb exhibits a relatively well-ordered concentric spatial pattern. These results correspond to the research into the pre-transition phase of the city's development (Bašić 1994a, 1994b, 1994c; Marinović-Uzelac 1978), and with the socio-spatial structure of individual cities in other postsocialist countries in transition (Sykora 1999a; Rebernik 2002).

\section{Salaries.}

Previous research (Sykora 1994, 1999a, 1999b) into postsocialist cities has established that since the commencement of the transition period, there has been considerable differentiation among populations in terms of average incomes (salaries). Differences in income levels (salaries) are one of the primary indicators of the increasingly apparent social differentiation. Sykora (1999a), using the example of Prague, stresses that the growing differences between the highest and lowest average salaries is leading to the appearance of social polarization, just as in some cities in countries with developed market economies. It is assumed that during the transition period, differences between average net salaries were a major modifier of the socio-spatial structure in Zagreb as well, and that the differences between individual social groups increased considerably.

Unfortunately, official statistics do not record data on income rates, so that in this case indicators of average net salaries for select economic activities during the 1998-2001 period and for qualifications in 2001 at the city-wide level will be used. Unfortunately, these data are not released for the city district level, only at the city-wide level, so there is no orderly and processed statistical documentation for preceding periods. Data on average net salaries also have certain shortcomings. They only show differences in the level of income within the employed contingent. This excludes the unemployed, the retired, persons on social welfare, persons earning income from rents, etc. 
If deviations from average net salaries are observed based on select economic activities during the 1998-2001 period, one can see that the highest average net salaries were earned by those employed in financial mediation, while average net salaries in the construction branch were the lowest. The standard deviation values indicate a growing tendency in the deviation of average salaries in individual activities from the overall average, i.e. increasing differences between individual activities (Tab. 2). They are particularly striking, as noted previously, between financial mediation and construction, i.e. between the tertiary and secondary sector, in which the highest and lowest paid occupations are concentrated. Average net salaries of the employed based on qualifications also deviate considerably from the average. This is shown by the data that employed persons with college and university qualifications have salaries that are approximately $50 \%$ above average, while on the other hand unskilled workers have salaries almost $40 \%$ below the average (Tab. 3 ).

Tab. 2 Average net salaries in select activities in the City of Zagreb, 1998-2001

Tab. 2. Prosječna neto plaća u odabranim djelatnostima Grada Zagreba 1998.-2001.

\begin{tabular}{|l|r|r|r|r|r|r|r|r|}
\hline Activities & $\mathbf{1 9 9 8}$ & $\mathbf{\%}$ & $\mathbf{1 9 9 9}$ & $\mathbf{\%}$ & $\mathbf{2 0 0 0}$ & $\mathbf{\%}$ & $\mathbf{2 0 0 1}$ & $\mathbf{\%}$ \\
\hline Agriculture & 2910 & 96,5 & 2903 & 83,5 & 3170 & 83,1 & 3232 & 78,5 \\
\hline Mining and extraction & 3098 & 102,7 & 3414 & 98,2 & 4040 & 105,9 & 4490 & 109,0 \\
\hline Manufacturing & 3019 & 100,1 & 3307 & 95,1 & 3613 & 94,7 & 4045 & 98,2 \\
\hline $\begin{array}{l}\text { Electricity, natural gas and } \\
\text { water supply }\end{array}$ & 3169 & 105,0 & 3722 & 107,1 & 3965 & 103,9 & 4136 & 100,4 \\
\hline Construction & 2511 & 83,2 & 2812 & 80,9 & 2756 & 72,2 & 3129 & 76,0 \\
\hline $\begin{array}{l}\text { Sales, repair of motor vehicles } \\
\text { and household appliances }\end{array}$ & 2739 & 90,8 & 2840 & 81,7 & 3091 & 81,0 & 3395 & 82,4 \\
\hline Hotels and restaurants & 2525 & 83,7 & 2865 & 82,4 & 3072 & 80,5 & 3290 & 79,9 \\
\hline $\begin{array}{l}\text { Transportation, warehousing } \\
\text { and communications }\end{array}$ & 3073 & 101,9 & 3624 & 104,3 & 4080 & 106,9 & 4445 & 107,9 \\
\hline Financial mediation & 4246 & 140,7 & 4890 & 140,7 & 5625 & 147,4 & 6225 & 151,2 \\
\hline $\begin{array}{l}\text { Real estate transactions, leasing } \\
\text { and business services }\end{array}$ & 3289 & 109,0 & 3794 & 109,1 & 4113 & 107,8 & 4396 & 106,8 \\
\hline $\begin{array}{l}\text { Public administration and } \\
\text { defense; compulsory social } \\
\text { security }\end{array}$ & 3301 & 109,4 & 4319 & 124,3 & 4600 & 120,6 & 4468 & 108,5 \\
\hline Education & 2766 & 91,7 & 3310 & 95,2 & 3703 & 97,1 & 3949 & 95,9 \\
\hline Health-care and social welfare & 2979 & 98,7 & 2652 & 76,3 & 4151 & 108,8 & 4360 & 105,9 \\
\hline $\begin{array}{l}\text { Other social and personal } \\
\text { services }\end{array}$ & 3095 & 102,6 & 3512 & 101,0 & 3732 & 97,8 & 3960 & 96,2 \\
\hline Average salary & 3017 & 100,0 & 3476 & 100,0 & 3815 & 100,0 & 4118 & 100,0 \\
\hline Standard deviation & 424,1 & 14,1 & 629,2 & 18,1 & 728,8 & 19,1 & 783,1 & 19,0 \\
\hline
\end{tabular}

Source: Statistički ljetopis Zagreba 2002., Gradski zavod za planiranje razvoja grada i zaštitu okoliša, Zagreb, 2002.

Izvor: Statistički ljetopis Zagreba 2002., Gradski zavod za planiranje razvoja grada i zaštitu okoliša, Zagreb, 2002 
Tab. 3 Average net salaries of the employed based on qualifications in the City of Zagreb

Tab. 3. Prosječna neto plaće zaposlenih prema stupnju stručne sprema u Gradu Zagrebu

\begin{tabular}{|l|r|r|}
\hline Qualifications & $\begin{array}{c}\text { Average net } \\
\text { salary in HRK }\end{array}$ & \multicolumn{1}{|l|}{ Index } \\
\hline University & 6276 & 152,40 \\
\hline College & 4575 & 111,10 \\
\hline Secondary & 3735 & 90,70 \\
\hline Lower & 2838 & 68,92 \\
\hline Highly skilled & 3957 & 96,09 \\
\hline Skilled & 3169 & 76,95 \\
\hline Semi-skilled & 2824 & 68,58 \\
\hline Unskilled & 2558 & 62,12 \\
\hline Average & 4118 & 100,00 \\
\hline
\end{tabular}

Source: Statistički ljetopis Zagreba 2002., Gradski zavod za planiranje razvoja grada i zaštitu okoliša, Zagreb, 2002.

Izvor: Statistički ljetopis Zagreba 2002., Gradski zavod za planiranje razvoja grada i zaštitu okoliša, Zagreb, 2002.

A comparison of the results obtained here to similar research (Sykora 1999a, 1999b) lead to the conclusion that during the transition period an increase in inequality based on salary levels was present, and this corresponds to similar trends in other postsocialist cities.

\section{Unemployment.}

An important feature of postsocialist cities is the change in the structure of activities and the associated growth in the number of unemployed. The transition from a planned to a market economy leads to a decline in the importance of production activities and number of those employed in this branch. These changes have not bypassed Zagreb. Although Zagreb was already a tertiary city in 1981 (Vresk 1986), this function during the transition period became even more marked. The share of the employed in production decline from $30 \%$ in 1981 to $20 \%$ in $2001 .^{5}$ The reduction in the share of the employed in production activities was accompanied by an increase in unemployment. The most recent research confirms that besides de-industrialization processes, privatization and economic transformation also had a considerable impact on growth in unemployment, as did the direct repercussions of Croatia's Homeland War. Not all of the objectives of economic transformation and privatization have been achieved, and there were in fact negative consequences from the political, economic and social standpoints. Among the latter, unemployment was one of the most problematic (Bendeković 2001; Lasić 2001). During the 1990-2001 period, the total number of unemployed in the City of Zagreb increased by almost $135 \%$ ! A drastic rise was recorded in the first half of the 1990s, when the number of unemployed rose from 25,482 in 1990 to 49,836 two years later. By 1996 unemployment had stagnated but then again experienced a spurt of growth, so that by 2001 it had reached a level of 59,914 unemployed persons, or a rate of $16.8 \%$. 
Unemployment, particularly when extensive and of a long duration, can have a considerable impact on a city's socio-spatial structure. The areas of a city beset by this problem become socially and physically devastated, while the population in them becomes excluded from the social and economic mainstream (Pacione 2001).

Due to a lack of data on the structure of unemployment, unemployment rates by city district are shown for 2001 (Fig. 3). The unfavorable impact of these transition processes

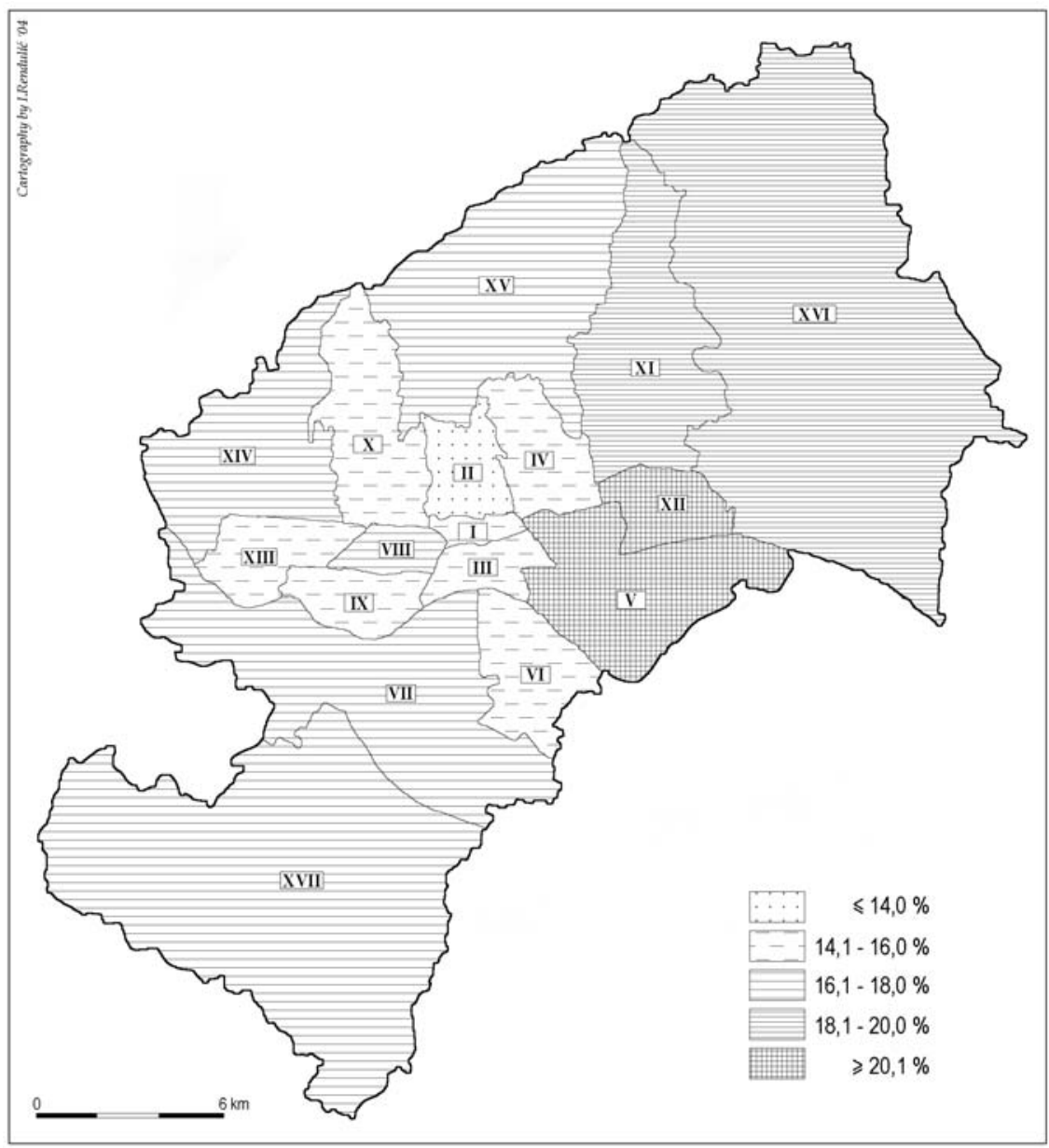

Fig. 3 Unemployment rates by city district in the City of Zagreb in 2001

(I Donji grad, II Gornji grad-Medveščak, III Trnje, IV Maksimir, V Pečćenica-Žitnjak, VI Novi Zagreb-istok, VII Novi Zagreb-zapad, VIII Trešnjevka-sjever, IX Trešnjevka-jug, X Črnomerc, XI Gornja Dubrava, XII Donja Dubrava, XIII Stenjevec, XIV Podused-Vrapče, XV Podsljeme, XVI Sesvete, XVII Brezovica)

Sl. 3. Stope nezaposlenog stanovništva po gradskim četvrtima Grada Zagreba 2001. godine

(I Donji grad, II Gornji grad-Medveščak, III Trnje, IV Maksimir, V Pečćenica-Žitnjak, VI Novi Zagreb-istok, VII Novi Zagreb-zapad, VIII Trešnjevka-sjever, IX Trešnjevka-jug, X Črnomerc, XI Gornja Dubrava, XII Donja Dubrava, XIII Stenjevec, XIV Podused-Vrapče, XV Podsljeme, XVI Sesvete, XVII Brezovica) 
is visible in all parts of the city. Districts in the city center deviate from the average rate in the "positive" sense (Gornji grad-Medveščak, $12.4 \%$; Donji grad, 14.3\%), as do districts in the wider city center (Maksimir, $14.1 \%$ and others). The highest unemployment rates are present in peripheral districts (Donja Dubrava 21.7\% and Novi Zagreb-istok). This is completely understandable as these are city sections that traditionally had the highest share of employed in production (Vresk 1986), of whom many lost their jobs during the transition period due to more intense de-industrialization.

The correlation between unemployment rates and educational structure is interesting. A comparison shows great spatial correspondence between these two socio-economic indicators (Fig. 1, 2 and 3). The central parts of the city with the best educational structure (Donji grad and Gornji grad-Medveščak) have the lowest unemployment rates, while the situation is the reverse in peripheral zones. Traditionally industrial districts with a lower educational structure record above average unemployment.

\section{CONCLUSION}

A comparison of previous research into the socio-spatial structure of cities reveals great differences between cities in countries with developed market economies and cities in postsocialist countries. While the socio-spatial structure is conspicuously differentiated and exhibits polarizing features in the former, in the postsocialist countries the process of transition over roughly the last decade has considerably influenced the creation of increasingly greater differences in the until-then homogenous socio-spatial structure. Research has demonstrated that social differentiation is greatest in the distribution of income (salaries).

Despite the shortage of relevant statistical indicators, the preliminary results of the analysis of the socio-spatial structure of the City of Zagreb show specific changes in comparison to the preceding period. The spatial pattern of the pre-transition period sociospatial structure has been retained, while there has been an improvement in the educational structure in relation to the preceding period. Such a pattern is common to other postsocialist cities. The transition from a planned to a market economy has had a considerable impact on differences in average net salaries based on activity and qualifications. It is precisely in these deviations from the average that the beginnings of major changes within the sociospatial structures of a city can be discerned. These changes correspond to similar processes noted in other postsocialist cities. If changes in the structure of activities and the growing unemployment figures are added to this, a picture of the socio-spatial structure of the city is obtained in which the population's socio-economic status declines as one moves from the center to the peripheral sections of the city. 


\section{NOTES}

1. Cited according to the second edition: Sassen, S., 2001. The Global City. New York, London, Tokyo: Princeton Press, Princeton.

2. Under the Republic of Croatia County, City and Municipal Territories Act (Narodne novine, no. 10/97) and the City of Zagreb Act (Narodne novine, no. 90/92, 76/93, 69/95 and 14/97), the City of Zagreb is defined as a separate and unified territorial, administrative and self-governing unit which has the status of a county (Statistički ljetopis Grada Zagreba, 2002).

3. These are city districts which have the largest number of rural settlements that 'take down' the average.

4. In an analysis of Zagreb's social topography using data from 1981, Bašić stresses the following: “The high population density in the central city districts is the result of the high developmental density, even though the average housing floor-space per person here is the largest in the entire city, as is the average size of homes. If we add to this the connections of such homes with the basic utilities infrastructure, then it follows that the city center still offers the best housing conditions, despite the age of the buildings and the increasingly high concentration of business activities and circulation of people and goods. This is why it is not surprising that it is precisely the central city districts that have the best educational structure as an indicator of their higher economic status (Bašić, 1994a, 38)." Accordingly, a similar spatial pattern was retained even twelve years later (author's emphasis).

5. Due to changes in the classification of activities, data on the share of employed in manufacturing activities in 1981-2001 are not fully comparable. According to the national classification of activities, the term industry encompasses the following three fields: mining and extraction, manufacturing, and electricity, natural gas, and water supply (Statistički ljetopis Grada Zagreba, 2002).

\section{REFERENCES}

Andersen H. S., Andersen H. T., Ærø T., 2000: Social polarisation in a segmented housing market: Social segregation in Greater Copenhagen, Geografisk Tidsskrift 100, 71-83

Andersen H. T., 2002: Globalisation, spatial polarization and the housing market, Geografisk Tidsskrift 102, 93-102

Badcock B., 1997: Restructuring and spatial polarization in cities, Progress in Human Geography 21 (2), 251262

Bašić K., 1994a: Socijalna topografija Zagreba - dihotomija grada i suburbija, Sociologija sela 32, 27-42

Bašić K., 1994b: Obiteljski status - aspekt socijalne topografije Zagreba, Geografski glasnik 56, 69-81

Bašić K., 1994c: Socijalno-prostorna segregacija stanovništva Zagreba, Geografski horizont 40 (2), 73-78

Bendeković J., 2001: Privatization in Croatia, Ekonomski pregled 51 (1-2), 55-90

Bruegel I., 1996: Gendering the Polarisation Debate: A Comment on Hamnett's "Social Polarisation, Economic Restructuring and Welfare State Regimes", Urban Studies 33 (8), 1431-1439

Burgers J., 1996: No Polarisation in Dutch Cities? Inequality in a Corporatist Country, Urban Studies 33 (1), 99-105

Castells M., 1989: The Informational City, Blackwell, Oxford

Castells M., 1996: The Informational Economy and the New Division of Labor, in Daniels S., Lee R. (eds.) Exploring Human Geography, A Reader, Arnold, London

Clark W.A.V., McNicholas M., 1996: Re-examing economic and social polarisation in multi-ethnic Metropolitan area: the case of Los Angeles, Area 28 (1), 56-63 
Hamnett C., 1994: Social polarisation in global cities: Theory and evidence, Urban Studies 31 (3), 401-424

Hamnett C., 1996a: Why Sassen is Wrong: A Response to Burgers, Urban Studies 33 (1), 107-110

Hamnett C., 1996b: Socioeconomic Polarisation, Economic Restructuring and Welfare State Regimes, Urban Studies 33 (8), 1407-1430

Hamnett C., 1998: Social Polarization and Inequality in Europe, Nederlandse Geographische Studies 21, 32-40

Hamnett C., 2001: Social Segregation and Social Polarization, in Paddison, R. (ed.) Handbook of Urban Studies, Sage, London, 162-176

Hamnett C., Cross D., 1998: Social change, social polarisation and income inequality in London, 1979-1993, Geojournal 46 (1), 39-50

Häußermann H. (1997): Von der sozialistischen zur kapitalistischen Stadt, in Kovács Z., Wießner R. (eds.) Prozesse und Perspektiven der Stadtentwicklung in Ostmitteleuropa, Münchner Geographische Hefte 76, Passau, 21-32

Kostinskiy G., 2001: Post-Socialist Cities in Flux, in Paddison, R. (ed.) Handbook of Urban Studies, Sage, London, 451-465

Lasić V., 2001: Koncept modela privatizacije u Hrvatskoj, Ekonomski pregled 51 (1-2), 107-117

Marinović-Uzelac A., 1978: Socijalni prostor grada, Sveučilišna naklada Liber, Zagreb

Pacione M., 2001: Urban Geography: A Global Perspective, Routledge, London

Rebernik D, 2002: Socialnogeografska zgradba in preobrazba Ljubljane, in Pak, M. (ed.) Geografija Ljubljane, Oddelek za geografijo Filozofske fakultete Univerze v Ljubljani, Ljubljana, 85-116

Sassen S., 2001: The Global City: New York, London, Tokyo, Princeton Press, Princeton

Stouten P., 2000: Divisions in Dutch Cities, City 4 (3), 341-362

Sykora L., 1994: Local urban restructuring as a mirror of globalization processes: Prague in the 1990s, Urban Studies 31 (7), 1149-1166

Sykora L., 1999a: Processes of socio-spatial differentiation in post-communist Prague, Housing Studies 14 (5), 679-701

Sykora L., 1999b: Chages in the internal spatial structure of post-communist Prague, Geojournal 49 (1), 79-89 van Kempen E.T., 1994: The dual city and the poor: Social polarisation, social segregation and life chances, Urban Studies 31 (7), 995-1015

Vresk M., 1986: Neki pokazatelji funkcionalno-prostorne strukture Zagreba, Radovi 21, 45-53

Vresk M., 2002: Grad i urbanizacija: osnove urbane geografije, Školska knjiga, Zagreb

Węcławowicz G., 1997: The changing socio-spatial patterns in Polish cities, in Kovács Z., Wießner R. (eds.) Prozesse und Perspektiven der Stadtentwicklung in Ostmitteleuropa, Münchner Geographische Hefte 76, Passau, 75-82

Wessel T., 2000: Social Polarisation and Socioeconomic Segregation in a Welfare State: The Case of Oslo, Urban Studies 37 (11), 1947-1967

Wessel T., 2001: Understanding Changes in Urban Income Inequality and Social Divisions: Theories and Evidence in Contemporary Western Cities, in Davis, W.K.D., Townshend, I.J. (eds.) Monitoring Cities: International Perspective, International Geographic Union, Urban Comission, Calgary, 501-521

Wießner R., 1997: Sozialräumliche Polarisierung der inneren Stadt Budapest, in Kovács Z., Wießner R. (eds.) Prozesse und Perspektiven der Stadtentwicklung in Ostmitteleuropa, Münchner Geographische Hefte 76, Passau, 189-202

Woodward R., 1995: Approaches towards the study of social polarization in the UK, Progress in Human Geography 19 (1), 75-89 


\title{
SAŽETAK
}

\section{Socijalno-prostorna struktura grada: primjer Zagreba}

\author{
Vedran Prelogović
}

Socijalne razlike u gradovima, osobito u posljednjih dvadesetak godina, tema su mnogih geografskih istraživanja. Interes je najviše došao do izražaja u radovima američkih i zapadnoeuropskih istraživača, a raspadom socijalističkog društvenog uređenja i velikim promjenama uslijed toga, značajnu pažnju toj problematici posvećuju i znanstvenici iz Srednje i Istočne Europe. Istraživanja su pokazala da je socijalno-prostorna struktura grada tijesno povezana sa društveno-ekonomskim razvitkom i urbanizacijom, te se stoga ističu razlike između razvijenih i slabije razvijenih zemalja.

Promjene socijalno-prostorne strukture u gradovima zemalja razvijenog tržišnog gospodarstva treba ponajprije vezati uz procese globalizacije i informatizacije, odnosno uz pojavu informacijskog društva. Primjena novih tehnologija u proizvodnim i uslužnim djelatnostima, te restrukturiranje kapitalizma, vidljivi su u ekonomskoj, političkoj, socijalnoj i kulturnoj sferi života. Sve više istraživanja potvrđuje da u gradovima zemalja razvijenog tržišnog gospodarstva dolazi do pojave socijalne polarizacije. Tezu o socijalnoj polarizaciji u gradovima prva je iznijela Saskia Sassen. Polazi od pretpostavke da je socijalna polarizacija, izražena u prihodima i zanimanjima, posljedica prestrukturiranja proizvodnih u uslužne djelatnosti. Socijalna polarizacija je najprije uočena u visoko razvijenim zemljama, ponajprije u globalnim gradovima. Glavna prostorna manifestacija je porast gornjeg i donjeg na štetu srednjeg socijalnog sloja. Ističe tri bitna elementa koja doprinose polarizaciji: porast uslužnih i smanjenje udjela proizvodnih djelatnosti (tercijarizacija), porast visoko plaćenih radnih mjesta koja povećavaju potražnju slabije plaćenih radnih mjesta, te informatizaciju proizvodnih djelatnosti. Mnogobrojna istraživanja u svijetu potvrdila su, ali i ukazala na složenost te pojave. Zbog drugačijeg političkog, ekonomskog i socijalnog konteksta u kojem se mijenja socijalno-prostorna struktura u američkim i zapadnoeuropskim gradovima, pojedine pretpostavke u teoriji socijalne polarizacije su dovedene u pitanje ili su opovrgnute. To se posebno odnosi na sve veći rast donjeg sloja, tj. pojavu novog siromaštva u gradovima, što je dokazano samo u nekima globalnim gradovima.

Raspadom socijalističkog društvenog uređenja gradovi u Srednjoj i Istočnoj Europi nalaze se u tranziciji iz socijalističkog u kapitalistički oblik grada. Proces tranzicije iz planske u sustav tržišne ekonomije imao je značajne posljedice na ekonomske, političke i socijalne strukture. Vidljiv i naglašen aspekt tih promjena osobito je izražen u socijalno-prostornoj strukturi gradova. Poslije 1990. godine dolaze do izražaja sljedeće pojave: raste broj nezaposlenih, izraženije je socijalno razdvajanje, povećava se udio viših i nižih socijalnih slojeva te se šire zone socijalne ekskluzije. Nezaposlenost, siromaštvo i rastuća socijalna polarizacija najistaknutija su suvremena obilježja socijalno-prostorne strukture gradova postsocijalističkih zemalja. 
Rezultati dosadašnjih istraživanja (do 1990-ih) socijalno-prostorne strukture Zagreba pokazuju stanje slično onom u ostalim socijalističkim gradovima prije tranzicije. Socijalnoprostorna struktura odraz je naslijeđene slike iz predratnog razdoblja (do 1945. godine), koju karakterizira izraženija razlika između socijalnih slojeva stanovništva, i nastojanja socijalističkih vlasti da se te razlike što više smanje. Pred početak tranzicijskog razdoblja (1980-ih godina) u Zagrebu je sve prisutnija diferenciranost s obzirom na socijalnoekonomski i obiteljski status stanovništva, no socijalno-prostorna struktura je još uvijek relativno homogena u usporedbi s gradovima Zapadne Europe.

U radu se iznose preliminarni rezultati istraživanja socijalno-prostorne strukture Zagreba koje je izvršeno u okviru projekta «Urbani sistem i prostorna organizacija Hrvatske». Osnovno polazište rada je da se u posljednjih 20-ak godina i u Zagrebu mijenja socijalno-prostorna struktura.

Analiza se temelji na statističkim podacima popisa stanovništva, kućanstava i stanova 2001. godine. Prostor istraživanja je upravno-teritorijalna jedinica Grad Zagreb, a razina analize podataka je 17 gradskih četvrti, obzirom da su to najmanje prostorne jedinice za koje postoji sređena i objavljena statistička dokumentacija. Upravo nedostatak objavljenih podataka na nižim razinama onemogućava stvaranje realnije slike o stanju socijalno-prostorne strukture. U obzir su uzeti sljedeći socijalno-ekonomski pokazatelji: obrazovna struktura, place i nezaposlenost. Smatra se da se u navedenim pokazateljima najbolje zrcale promjene u tranzicijskom razdoblju i da će najveća odstupanja između pojedinih kategorija stanovništva, slično kao i u drugim postsocijalističkim gradovima, biti upravo izražena navedenim pokazateljima.

Istraživanjima je utvrđeno da je obrazovna struktura jedan od najboljih pokazatelja socijalno-ekonomskog statusa stanovništva. Prema rezultatima posljednjeg popisa 2001. u Gradu Zagrebu je 8,6 \% obuhvaćenog kontingenta bilo bez ikakve školske spreme is nedovršenom osnovnom školom. Pridoda li se tome i 16,3 \% sa završenom samo osnovnom školom, dobiva se podatak da je u Gradu Zagrebu 2001. godine L' stanovništva imala nedovoljnu obrazovnu razinu. Bez obzira na istaknuti negativni podatak, takva je struktura bitni napredak u odnosu na stanje prije deset ili dvadeset godina, koji se očituje u povećanju udjela srednje i visoko obrazovanog i smanjenju udjela slabije obrazovanog stanovništva (tab. 1). Poboljšanje obrazovne strukture posljedica je opće tendencije podizanja kvalitete života, smanjenog doseljavanja slabije obrazovanog stanovništva iz ruralnih krajeva Hrvatske i republika bivše države (osobito iz $\mathrm{BiH}$ ) koje je «kvarilo» prosjek i unutargradskog preseljavanja dijela stanovništva (mlađeg i bolje obrazovanog) iz središnjih u rubne dijelove grada. «Spustimo» li se na razinu gradskih četvrti dobivamo heterogenu sliku obrazovne strukture stanovništva (sl. 1 i 2). Ističu se razlike u krajnjim kategorijama obrazovnih skupina. Udio stanovništva bez škole i s nedovršenom osnovnom školom kreće se od 3,8 \% u Gornjem gradu-Medveščaku do 13,0 \% u Donjoj Dubravi, tj. 15,0 \% i 22,4 \% u Sesvetama i Brezovici. Obrazovna razina smanjuje se udaljavanjem od središta grada, a područja s visokim udjelom visoko obrazovanih imaju najmanje onih sa slabom naobrazbom i obrnuto, što je ujedno i dokaz njihove unutarnje homogenosti (sl. 1 i 2 ). 
Ustanovljeno je da je u postsocijalističkim gradovima od početka tranzicijskog razdoblja prisutna značajna diferencijacija stanovništva prema prosječnoj visini prihoda (plaća). Razmotre li se odstupanja od prosječne neto plaće prema odabranim ekonomskim djelatnostima u razdoblju 1998.-2001., uočava se da su najvišu prosječnu neto plaću imali zaposleni u financijskom posredovanju, dok je u građevinarstvu prosječna plaća bila najniža. Vrijednosti standardne devijacije upućuju na tendenciju povećanja odstupanja prosječnih plaća u pojedinim djelatnostima od ukupnog prosjeka tj. na povećanje razlika među pojedinim djelatnostima. (tab. 2). One su osobito naglašene između financijskog poslovanja i građevinarstva, tj. između tercijarnog i sekundarnog sektora u kojima se koncentriraju najbolje odnosno najslabije plaćena zanimanja. Prosječne neto plaće zaposlenih prema stupnju stručne spreme također značajno odstupaju od prosjeka. O tome svjedoči podatak da zaposleni s višom i visokom stručnom spremom imaju oko 50,0 \% višu plaću od prosjeka, dok s druge strane nekvalificirani imaju gotovo 40,0 \% nižu plaću od prosjeka (tab. 3).

Važno obilježje postsocijalističkih gradova jesu promjene u strukturi djelatnosti i povezano s tim porast broja nezaposlenih. U razdoblju 1990.-2001. ukupan broj nezaposlenih u Gradu Zagrebu se povećao gotovo 135\%! Nagli porast zabilježen je u prvoj polovici 1990-ih, kada se broj nezaposlenih povećao sa 25 482, 1990. godine na 49836 dvije godine kasnije. Do 1996. godine nezaposlenost je stagnirala kada ponovno bilježi nagli porast, da bi 2001. godine dosegla razinu od 59914 nezaposlenih ili stopu od $16,8 \%$. Nepovoljan utjecaj tranzicijskih procesa vidljiv je u svim dijelovima grada. Od prosječne stope $\mathrm{u}$ «pozitivnom» smislu odstupaju četvrti središnjeg dijela grada (Gornji grad-Medveščak 12,4 \%, Donji grad 14,3 \%) i četvrti šireg središta grada (Maksimir 14,1 $\%$ i druge) Najviše stope nezaposlenosti prisutne su u rubnim gradskim četvrtima (Donja Dubrava 21,7\% i Novi Zagreb-istok ) (sl.3). To je posve razumljivo jer je riječ o dijelovima grada s tradicionalno najvećim udjelom zaposlenih u proizvodnim djelatnostima, od koji su mnogi u razdoblju tranzicije i pojačane deindustrijalizacije ostali bez posla. Usporede li se stope nezaposlenosti i obrazovna struktura stanovništva, uočava se velika prostorna podudarnost ovih dvaju socijalno-ekonomskih pokazatelja (sl.1, 2 i 3). Središnji dijelovi grada s najboljom obrazovnom strukturom (Donji grad i Gornji grad-Medveščak) imaju najniže stope nezaposlenosti, dok je u rubnim zonama situacija obrnuta. Tradicionalne industrijske četvrti sa slabijom obrazovnom strukturom stanovništva bilježe iznadprosječnu nezaposlenost.

Usporedba dosadašnjih istraživanja socijalno-prostorne strukture grada otkriva bitne razlike između gradova razvijenog tržišnog gospodarstva i gradova u postsocijalističkim zemljama. Dok je u prvima socijalno-prostorna struktura izrazito diferencirana i pokazuje polarizirana obilježja, u postsocijalističkim gradovima proces tranzicije u posljednjih 10-ak godina bitno je utjecao na stvaranje sve većih razlika u dotad relativno homogenoj socijalno-prostornoj strukturi. Istraživanja pokazuju da je socijalna diferencijacija najizraženija u distribuciji prihoda (plaća) stanovništva.

Unatoč oskudnosti relevantnih statističkih pokazatelja, preliminarni rezultati analize socijalno-prostorne strukture Grada Zagreba pokazuju određene promjene u odnosu 
na prethodno razdoblje. Zadržan je prostorni obrazac socijalno-prostorne strukture iz predtranzicijskog razdoblja, poboljšanje u odnosu na prethodno razdoblje izraženo je u obrazovnoj strukturi. Takav obrazac karakterističan je i za druge postsocijalističke gradove. Prijelaz s planskog na tržišno gospodarstvo značajno je utjecao i na razlike u visini prosječnih neto plaća po djelatnostima i stručnoj spremi. Upravo se u odstupanjima od prosjeka mogu razabrati počeci značajnije promjene unutar socijalno-prostorne strukture grada. Navedene promjene u skladu su sa sličnim procesima ustanovljenim i u drugim postsocijalističkim gradovima. Pridodaju li se prethodnim pokazateljima i promjene u strukturi djelatnosti i sve veći broj nezaposlenih, dobiva se slika socijalno-prostorne strukture grada u kojemu se socijalno-ekonomski status stanovništva snižava se od središnjih prema rubnim dijelovima grada.

Received (Primljeno): 2004 - 5 - 25

Accepted (Prihvaćeno): $2004-6$ - 14

Vedran Prelogović, Junior researcher/assistant, Department of Geography, Faculty of Science, Marulićev trg 19/II,

10000 Zagreb, Croatia,

e-mail: vprelogo@geog.pmf.hr 